\title{
Can Alternative Indicators Overcome Language Biases in Citation Counts? A Comparison of Spanish and UK research ${ }^{1}$
}

\author{
Amalia Mas-Bleda², Mike Thelwall \\ Statistical Cybermetrics Research Group, School of Mathematics and Computer Science, University of \\ Wolverhampton, Wulfruna Street, Wolverhampton WV1 1LY, West Midlands, UK
}

\begin{abstract}
This study compares Spanish and UK research in eight subject fields using a range of bibliometric and social media indicators. For each field, lists of Spanish and UK journal articles published in the year 2012 and their citation counts were extracted from Scopus. The software Webometric Analyst was then used to extract a range of altmetrics for these articles, including patent citations, online presentation mentions, online course syllabus mentions, Wikipedia mentions and Mendeley reader counts and Altmetric.com was used to extract Twitter mentions. Results show that Mendeley is the altmetric source with the highest coverage, with $80 \%$ of sampled articles having one or more Mendeley readers, followed by Twitter (34\%). The coverage of the remaining sources was lower than $3 \%$. All of the indicators checked either have too little data or increase the overall difference between Spain and the UK and so none can be suggested as alternatives to reduce the bias against Spain in traditional citation indexes.
\end{abstract}

\section{Introduction}

Research is often assessed with the aid of bibliometric indicators, such as the number of publications in citation-based databases like the Web of Science (WoS) and Scopus, and citation counts. These convenient sources of evidence can be easily used for comparing nations. Nevertheless, these databases (especially WoS) are biased towards literature in English by including a greater proportion of academic literature in English than in other languages. The major citation databases are also biased towards journal articles (Albarillo 2014; Archambault et al. 2006, Orduña-Malea et al. 2014; Van Leeuwen et al. 2001). This is a major drawback for humanities research and, to a lesser extent, social science research, because these have stronger national and regional orientations, tending to be published in languages other than English and often in books (Engels et al. 2012; Nederhof 2006). In addition, citation counts take time to accrue and only reflect scientific impacts inside academia.

These limitations have led to the development of new indicators for the impact of articles based on readership and downloads (Bollen et al. 2005), web citations and links (Thelwall and Kousha 2015a) and social media mentions (Thelwall and Kousha 2015b). A variety of web-based indicators have also been developed for the impact of books, software, datasets, videos and other non-standard academic outputs (Kousha and Thelwall 2015c). These indicators have the potential of reveal non-scholarly types of impacts, such as educational (from course syllabi and PowerPoint presentations), commercial (from patent citations) and social impacts (from Wikipedia citations) or attention (from Twitter). Moreover, they have the potential to avoid the language biases of traditional citation indexes because (almost) all countries can publish freely on the web and there is no selection process that works against nonEnglish content (unless perhaps search engines are used to gather data: Vaughan and Thelwall 2004).

\footnotetext{
${ }^{1}$ This is a post-print of an article to be published in the Journal Scientometrics (C) copyright 2016 Springer.

${ }^{2}$ Corresponding author: Amalia Mas-Bleda, amalia.mas@wlv.ac.uk
} 
Nevertheless, the alternative indicators also have their own biases and limitations (Bornmann 2014; Holmberg 2015). For instance, the majority of altmetric sources have a low coverage of academic publications and some social media indicators seem to be only valuable for the most recent publications (Costas et al. 2015a; Haustein et al. 2014). The main drawback of indicators based on social media is perhaps their susceptibility for gaming (Jamali et al. 2016; Wouters et al. 2015). In addition, some countries probably publish more content online than others and there are national differences in the uptake of social websites (Graham et al. 2011; Shim and Yang 2009) and so international biases could still be expected from indicators derived from the web or from specific social websites.

Whilst most alternative indicators have been assessed for individual disciplines, they have not been evaluated from the perspective of comparing research from different nations, although one study (Fairclough and Thelwall 2015b) has investigated the use of Mendeley readership data for early impact calculations to compare countries. In response, this study compares research in Spain to research in the UK using a combination of Scopus-based indicators (publication counts and citation counts) and social media indicators (online patent citations, online presentation mentions, online syllabus mentions, Wikipedia mentions, Mendeley readership counts and Twitter mentions). The goal is to assess whether the new indicators can be less biased against Spain relative to the UK than are traditional citation based indicators and whether they can give useful extra information about the relative strengths of Spain.

\section{Background}

Early attempts to derive alternative indicators from the internet assessed web citations (Cronin 2001; Davis 2002; Kousha and Thelwall 2007a; Vaughan and Shaw 2003, 2004) and URL citations (Kousha and Thelwall 2006) counted from the web as a whole. Since the web contains many unwanted types of citation, such as publisher tables of contents and library article listings, later studies produced indicators from specific parts of the web. Some indicators were based on specific types of website, such as science blogs (Shema et al. 2012) and and others used individual types of document, such as online presentations (Thelwall and Kousha 2008) and online syllabi (Kousha and Thelwall 2008). More recently, indicators derived from social media (e.g., social bookmarks, comments, tweets) have emerged (Mas-Bleda and Aguillo 2015), known as altmetrics (Priem et al. 2010), influmetrics (Cronin 2001; Rousseau and Ye 2013), scientometrics 2.0 (Priem and Hemmiger 2010) and social media metrics (Stuart 2009).

Several studies have suggested that altmetrics complement citations rather than being alternatives (Haustein et al. 2014). Moreover, altmetrics are less useful in fields with very low altmetric scores, including mathematics, computer science, and natural science and engineering (Costas et al. 2015a). All alternative indicators have different properties, however, and need to be analysed individually.

\section{Online patent citations}

A patent is a set of legal rights granted to an inventor within a particular country or set of countries that give exclusive rights for commercial use for a predetermined period. Patents are regarded important evidence of innovation, so citations from patents suggest that the cited documents have some technological or economic value for the innovation (Lo 2010; Meyer 2003; Narin et al. 1997). There are similarities and differences between patent and paper citations and one important difference is that both authors and examiners decide which publications should be cited by patents (Meyer 2000).

Patents reference both patents and non-patent documents (Callaert et al. 2006; Michel and Bettels 2001; Schmoch 1993). Non-patent references can be exploited for indicators of the innovation potential of published research (Tijssen et al. 2000). This is important because some types of research 
may be more useful for inventors than for scholars (Kousha and Thelwall 2015b). For instance, one conference paper had not received any WoS citations by October 2014, but had been formally cited in 14 patents (Wouters et al. 2015, p. 74), and a technical paper without any Scopus citations (by March 2015) had 67 citations from patents (Kousha and Thelwall 2015b).

Patent citations can be extracted from patent databases, but this process needs timeconsuming manual searches that are impractical for large-scale studies. Google Patents includes the full text of patents and patent applications registered in the United States Patent and Trademark Office (USPTO) from 1790 and the European Patent Office (EPO) from 1978 ${ }^{3}$. Its full-text search capability allows to locate citations to academic publications, but automatic citation counting from Google Patents is also not possible (Wouters et al. 2015, p. 74). To address this issue a semiautomatic indirect method has been developed using automatic Bing searches to extract and filter patent citations from Google Patents to academic papers (Kousha and Thelwall 2015b). This method has been evaluated with 322,192 science and engineering Scopus articles from every second year for the period 1996-2012, getting a high degree of accuracy (98\%) and coverage. There was a low but statistically significant correlation between the Google Patents citations and Scopus citations, ranging from .361 to 0.053 (Kousha and Thelwall 2015b). Thus, Google Patents is a reasonable source for large scale patent citation counts.

\section{Online presentation citations}

Presentations in form of PowerPoint slides can be used for lectures and talks by academics to students or other researchers. PowerPoint seems to be popular amongst educators (Uz et al. 2010) and its use is not restricted to English speaking nations, as evidence from Colombia confirms (Jaramillo et al. 2009). PowerPoint conference presentations are also popular (Hertz et al. 2015). Moreover, in some scientific fields, like computer science, engineering and mathematics, conferences play an important role (Goodrum et al. 2001; Moya-Anegón et al. 2014; Moed and Visser 2007) and citations to scientific publications from conference presentations may give important evidence of research impact in these fields.

Both teaching-related and research-related presentations can be posted on the web (including through sharing sites, such as slideshare.net, slideshow.com or slideplayer.com) and the content of the presentations is indexed by commercial search engines. Citations from online presentations can be automatically collected through the Bing API (Applications Programming Interface), using bibliographic information for the query together with the advanced search operator filetype:ppt to restrict the results to PowerPoint files (Thelwall and Kousha 2008).

\section{Online course syllabus mentions}

A syllabus is an academic document that provides information to students about their course (Fink 2012) and is a fundamental component of higher education (García Fernández and Deltell Escolar 2012). Syllabi often contain a list of required and recommended reading (Doolittle and Siudzinski 2010; Garavalia 1999; García Martín 2012; Matejka and Kurke 1994; Tung 2010). Mentions of academic publications in course reading lists can therefore be used as evidence of intellectual (Vaughan and Shaw 2005) or educational (Kousha and Thelwall 2008, 2015a) impact.

Since the emergence of the web, teaching and learning practices have changed (Web-based Education Commission 2000) including by posting syllabi online (Cummings et al. 2002). This practice is highly valued by college instructors (Bonk 2001) and departments that publish many syllabi online tend to produce high quality versions (Welsh 2000). Although it now seems to be common practice for universities to share course syllabi with students electronically, many of these may be in passwordprotected virtual learning environments and an unknown proportion are posted to the public web.

\footnotetext{
${ }^{3}$ https://support.google.com/faqs/answer/2539193
} 
Web or URL citations from class reading lists and syllabi have been found in several web citation studies (Vaughan and Shaw 2005; Kousha and Thelwall 2007a, 2007b). Moreover, two large-scale studies have shown that it is possible to count mentions to academic articles (Kousha and Thelwall 2008) and monographs (Kousha and Thelwall 2015a) in online academic syllabi using automatic Bing API searches. Marta-Lazo et al. (2014) found books to be preferably recommended in the course syllabi related to Communication and Education Degrees in Spanish Higher Education. Non-Spanish references were rarely recommended.

\section{Wikipedia mentions}

Wikipedia claims to be a multilingual, web-based, free encyclopaedia with openly editable content ${ }^{4}$. Wikipedia contributions are presumably influenced by pre-existing cultural differences (Pfeil et al. 2006; see also: Alonso-Jiménez 2015) and the existence of different language wikipedias attests to its international and multilingual spread.

Wikipedia is apparently less credible than some other online reference resources (Kubiszewski et al. 2011; Rector 2008) and seems to provide inaccurate, incomplete and poorly referenced information for some topics (Clauson et al. 2008; Lavsa et al. 2011). Its quality also seems to vary between language editions (see, for instance, Cabrera-Hernández 2013). However, according to Alexa.com ${ }^{5}$, it is the seventh most visited website in the world (February 2016), which demonstrates its societal value.

Within academia, both scholars and students use Wikipedia. Students use it to search for general information (Herbert et al., 2015), to obtain information about a topic (Head and Eisenberg 2010) and for scientific research (Weller et al. 2010). Lecturers only cautiously recommend Wikipedia to students (Eijkman 2010). Some scholars also use Wikipedia in their academic activities but others are reluctant to use it (Aibar et al. 2015; Chen 2010).

Wikipedia contributors often include academic and other references to support their statements (Luyt and Tan 2010). Academic publications cited in Wikipedia may therefore have some cultural or social utility. A study of drug-related Wikipedia articles (Koppen et al. 2015) found that half of the 601 cited references were journal articles and $6.5 \%$ were books. This was corroborated by a large-scale study of Wikipedia mentions of 302,328 Scopus-indexed English articles and 18,735 Scopus-indexed English monographs from multiple subject fields (Kousha and Thelwall 2016a). Journal articles were rarely cited in Wikipedia (5\% in all fields, ranging from $1 \%-11 \%)$, whereas a third of all monographs ( $33 \%$ in all fields, ranging from $22 \%-48 \%$ ) had received at least one Wikipedia citation.

\section{Mendeley readers}

Mendeley is a free web-based reference manager that allows users to create, organize and share lists of bibliographic references, as well as storing full text papers PDF format (Henning and Reichelt 2008). It has multidisciplinary coverage and includes different types of documents (e.g., articles, books, reports). Mendeley lets users connect with each other (Zaugg et al. 2011) and form groups (Jeng et al. 2015). Mendeley users can save publications in their personal libraries with the intention of reading and/or citing them for research, professional activities and teaching (Mohammadi et al. 2016).

Mendeley readership counts (Gunn 2013) are one of the potentially most promising metrics and the most similar to citations (Costas et al. 2015b). This indicator can be broken down by readers' occupations (Mohammadi et al. 2015, p. 1844) so that in some cases this metric may reflect traditional impacts and in other cases reflect other types of impacts (Li et al. 2012; Mohammadi et al. 2015). Mendeley readership counts may be particularly useful in social sciences and engineering areas where there are more Mendeley readers than Scopus citations (Mohammadi et al. 2015, p. 1844). They are also useful as early impact indicators because they tend to grow about a year before citations (Thelwall

\footnotetext{
${ }^{4}$ https://en.wikipedia.org/wiki/Wikipedia:About

${ }^{5}$ http://www.alexa.com/topsites
} 
and Sud 2015). Nevertheless, Mendeley has a bias towards junior researchers, since most of its users are PhD students, postgraduates and postdocs (Jeng et al. 2015; Mohammadi et al. 2015) and national biases, since Mendeley users tend to select articles from their own countries (Thelwall and Maflahi 2015).

\section{Twitter mentions}

Twitter is a web-based microblogging system allowing users to post short messages. It has social networking features, letting users connect with each other (Java et al. 2007). Scholars seem to use this platform for sharing scientific information as well as to network with peers (Letierce et al. 2010; Veletsianos 2012), although there are disciplinary differences (Holmberg and Thelwall 2014). Scholars also use Twitter to cite academic publications (Priem and Costello 2010; Tsou et al. 2015; Weller et al. 2011), sometimes reflecting intellectual impact, and there is some evidence that Twitter mentions may be an early predictor of traditional citations (Shuai et al. 2012).

Twitter seems to have a social orientation (Costas et al. 2015b) and more frequency cites scholarly publications than do other altmetric sources, including academic blogs, Facebook and Google+ (Costas et al. 2015a; Haustein et al. 2015; Thelwall et al. 2013). There is also evidence that a considerable number of Twitter mentions occur shortly after research is published (Eysenbach 2011; Priem and Costello 2010) and they seem to reflect attention, popularity or visibility rather than impact, so that Twitter mentions may be an early indicator of the level of attention (including publicity) that articles attract (Haustein et al. 2014).

\section{Research questions}

This study compares research in Spain to research in the UK using traditional indicators (publication and citation counts) and alternative indicators based mainly on the web and social media (patent citations, online presentation mentions, online course syllabus mentions, Wikipedia mentions, Mendeley reader counts and Twitter mentions) in order to seek evidence that any alternative indicators are less biased than citations. These indicators have been selected to reflect the educational, commercial, social or cultural impacts of research (Moed and Halevi 2015). They have been recommended for use by academics to demonstrate evidence of the value of their works (ACUMEN Portfolio 2014).

The research questions that drive this study are:

R.Q. 1: Do the alternative indicators have wide enough coverage to be useful?

R.Q. 2: Does the choice of indicator change the apparent strength of Spanish research relative to the U.K.?

\section{Methods}

\section{Research design and data collection}

This study compares Spanish and UK research using a range of bibliometric and altmetric indicators for a set of research fields chosen to represent Spanish strengths. This focus was chosen to ensure that the maximum amount of data was available for analysis because in some fields and years there were few Spanish-authored articles.

For each field, lists of journal articles with Spanish and UK authorship published in the year 2012 were extracted from Scopus on December 7, 2015. The Scopus limit is 5,000 articles per query, returning the most recent. For these fields with more articles, the same query was submitted in reverse date sort order to get the oldest 5,000 articles, giving up to 10,000 articles per field. The articles were taken from a single year to allow efficient comparisons and 2012 was selected to be 
recent enough to attract social web mentions and old enough to attract citations. Scopus was chosen because it is more comprehensive than the Web of Science (WoS), especially from an international perspective (Leydesdorff et al. 2010; Moed and Visser 2008; Moya-Anegón et al. 2007). Spanish scientific production also seems to be broader and better represented in Scopus than in WoS (Chinchilla-Rodríguez et al. 2014).

Information about 204,428 articles from 45 subject fields was downloaded from Scopus. Articles without DOIs were removed to ensure accurate matching between indicators, leaving 171,817 articles. It was selected the two fields with the most Spanish articles for the broad subject areas: social sciences and humanities; health sciences; life sciences; and physical sciences (Table 1). The veterinary field includes three subfields (with duplicates excluded): equine, food animals, and small animals. Duplicate and triplicate articles were found on veterinary field because the same article were within two or three subfields. Astronomy and astrophysics had the most articles for Spain but was excluded because of its large international team sizes.

Table 1. Journal articles with Spanish and UK authorship published in 2012 in eight fields indexed by Scopus.

\begin{tabular}{|c|c|c|c|c|c|}
\hline \multirow[b]{2}{*}{ Field name } & \multirow{2}{*}{$\begin{array}{c}\text { Number of } \\
\text { collected } \\
\text { articles }\end{array}$} & \multicolumn{4}{|c|}{ Collected articles with DOI } \\
\hline & & Total & Spain & UK & $\begin{array}{l}\text { Spain \& } \\
\text { UK }\end{array}$ \\
\hline Language and Linguistics & 10,000 & 6,899 & $312(4.5 \%)$ & 780 (11.3\%) & $10(0.1 \%)$ \\
\hline $\begin{array}{l}\text { Developmental and } \\
\text { Educational Psychology }\end{array}$ & 10,000 & 9,272 & $225(2.4 \%)$ & $977(10.5 \%)$ & $21(0.2 \%)$ \\
\hline Nutrition and Dietetics & 7,148 & 6,304 & $400(6.3 \%)$ & $518(8.2 \%)$ & $41(0.6 \%)$ \\
\hline Veterinary & 4,555 & 3,810 & $141(3.7 \%)$ & $276(7.2 \%)$ & $8(0.2 \%)$ \\
\hline Biotechnology & 10,000 & 8,395 & $286(3.4 \%)$ & $401(4.7 \%)$ & $10(0.1 \%)$ \\
\hline Neurology & 9,975 & 9,085 & $303(3.3 \%)$ & 812 (8.9\%) & $36(0.4 \%)$ \\
\hline Organic chemistry & 10,000 & 9,574 & $354(3.7 \%)$ & 376 (3.9\%) & $16(0.2 \%)$ \\
\hline Computational Mathematics & 8,034 & 7,420 & $334(4.5 \%)$ & 408 (5.5\%) & $12(0.2 \%)$ \\
\hline & 69,712 & 60,759 & $2,355(4 \%)$ & 4,548 (7.5\%) & $154(0.3 \%)$ \\
\hline
\end{tabular}

\section{Alternative metrics searching}

The software Webometric Analyst ${ }^{6}$ (Thelwall 2009) was used to conduct automatic searches with the Bing API (Bing is the only major search engine that supports API searches) and the web-based alternative indicators for the 2,355 Spanish and 4,548 UK articles (patents, presentations, syllabi, Wikipedia). This software was also used to gather Mendeley readers but the Altmetric.com record was used to get Tweets because these cannot be gathered retrospectively (Adie and Roe 2013; RobinsonGarcía et al. 2014).

- Patent citations. Queries used the first author last name, the first (up to) 10 terms of the article title as a phrase search, the publication year and site:google.com/patents to limit the results to the Google Patents website.

Ortega "Memory inhibition, aging, and the executive deficit hypothesis" 2012 site:google.com/patents

- Online presentation mentions. As above except using filetype:ppt as the limiting command to restrict the results to PowerPoint files.

Ortega "Memory inhibition, aging, and the executive deficit hypothesis" 2012 filetype:ppt

\footnotetext{
${ }^{6}$ lexiurl.wlv.ac.uk
} 
- Course syllabus mentions. As above except using syllabus as the limiting command, repeating the query with 'course description' as the limiting command and combining the two. In the example below, the vertical bar ' $I$ ' is an OR operator instruction to Webometric Analyst to run two queries at the same time, combining the results after removing duplicates. The results were automatically filtered by Webometric Analyst using a list of rules (Kousha and Thelwall 2015a) to remove matches that were likely to be incorrect.

Ortega "Memory inhibition, aging, and the executive deficit hypothesis" 2012 syllabus / Ortega "Memory inhibition, aging, and the executive deficit hypothesis" 2012 "course description".

- Wikipedia mentions. As above except using site:wikipedia.org/wiki/ to restrict the results to Wikipedia articles.

Ortega "Memory inhibition, aging, and the executive deficit hypothesis" 2012 site:wikipedia.org/wiki

- Mendeley readership counts. Mendeley readership counts for articles were collected via Webometric Analyst using the Mendeley API. Queries were created with the title of the article, the last name of the first author and publication year. DOls were not used as they are often absent in the Mendeley entries (Mohammadi et al. 2015) and there may be a UK/Spain difference in their prevalence. When no matches were found, zero Mendeley readers were assigned to the article.

title:"Memory inhibition, aging, and the executive deficit hypothesis" AND author:Ortega AND year:2012

- Twitter mentions. Twitter mentions data were extracted using altmetric.com, matching the article DOls. When no matches were found, zero Tweets were assigned to the article.

Queries were automatically created by Webometric Analyst ('Make Searches' menu) using the downloaded Scopus bibliographic information, with exception of Twitter mentions, which were extracted using altmetric.com.

\section{Data checking}

Before submitting the queries to Webometric Analyst, manual checking was needed, since some of the sampled articles $(318,4.5 \%)$ had titles in two languages. For these only the English title was kept. Slashes ' $\backslash$ ' before quotes (e.g.: |"Ser|") were also removed (78, 1.1\%). Errors in Spanish author names were also corrected, such as the inclusion of the author's first last name as part of the name, or problems with 'de', 'di', ' $i$ ', and 'van' in multi-word surnames. Finally, last names including apostrophes, accents and other non-standard characters were manually checked and modified for the queries.

After submitting the queries, false matches were manually identified and removed. False matches were particularly found for online presentation mentions and course syllabus mentions. Out of 337 online presentation mentions originally found for the sampled articles, 253 (75\%) were judged to be false matches. This was mainly because many scientific journals, especially related to veterinary science, neurology and nutrition, provided PPT files on their websites with images from the articles. These had the word 'ppt' in their URLs (e.g., http://www.jnutbio.com/article/S0955-2863(11)00135$5 / \mathrm{ppt})$. These journals complicate the gathering of online presentation mentions. Other false matches came from presentations reporting information about research projects or research groups, in which the queried author was part of the committee or the queried article was an output rather than a bibliographical reference.

Out of 312 course syllabus mentions originally found for sampled articles, 184 (59\%) were false matches, most coming from: 
- The Science.gov site (a gateway to United States scientific databases and websites) and online library catalogues. It was given a list of records for some terms that were totally irrelevant to terms utilized for our queries.

- Scientific databases or online scientific collections (sciencedirect.com, link.springer.com, tandfonline.com, mdpi.com). These seem to be academic publications citing the sampled articles.

- Academic social networks (Academia.edu and ResearchGate.net).

- Online CVs, researcher home pages, publication lists of researchers or departments and blogs.

Online course syllabi were restricted to the lists of undergraduate and graduate courses offered each trimester/semester/year by universities, so citations from other academic courses to the sampled articles were not taken into account. Similar pages were sometimes replicated within the same domaln the same syllabus with different formats (html, .doc, .pdf), syllabi for the same course for different academic years or for different versions (draft and definitive). Therefore, the syllabus mentions reported in the results section were counted by unique domain name rather than by URL as a simple way of filtering out duplicates.

\section{Statistical tests}

The geometric mean and a $95 \%$ confidence interval was calculated for each country, subject and indicator. Geometric means were used rather than arithmetic means because indicator values are typically highly skewed. For this calculation, 1 was added to each value before calculating the geometric mean and 1 subtracted from the result to deal with 0 s in the data, following standard practice (Fairclough and Thelwall 2015a). Confidence intervals can be calculated using the Student $t$ formula on the transformed data, also following standard practice.

\section{Results}

Out of 60,759 Scopus journal articles published in the eight selected fields in 2012 with a DOI, 2,355 (4\%) had one or more Spanish authors, 4,558 (7.5\%) had one or more UK authors and $154(0.3 \%)$ had at least one Spanish and at least one UK author. About a third (35\%) of the Spanish articles and $42 \%$ of the UK articles shared authorship with other nations. The main collaborators for Spanish articles were the United States (7\%), the United Kingdom (6.5\%), Italy (5\%), Germany (5\%) and France (4.3\%) whereas the main collaborators for UK articles were the United States (10.6\%), Germany (6\%), Italy $(4 \%)$ and the Netherlands (4\%). Spain collaborated in $3.4 \%$ of the UK articles. The dominance of the United States for international research collaboration is well known (Leydesdorff et al. 2013), including for Spain (Moya-Anegón et al. 2014; Plaza and Bordons 2006).

There were more UK than Spanish articles in the eight analysed fields (see Tables 2-3), although the numbers in 'organic chemistry' are similar. This reflects a much greater number of UK publications in Scopus overall compared to Spain (Chinchilla-Rodríguez et al. 2014).

\section{Scopus citations}

About $87 \%$ of the Spanish articles and $91 \%$ of the UK articles had one or more Scopus citations. Most subject fields had similar proportions of Spanish and UK articles with at least one Scopus citation, although more UK-authored articles were cited in computational mathematics (92\% vs. 84\%) and language and linguistics (79\% vs. 55\%).

Table 2. Bibliometric and altmetric information for the Spanish articles published in 2012 indexed by Scopus.

\begin{tabular}{|c|c|c|c|c|c|c|c|c|}
\hline Field name & $\begin{array}{l}\text { Sampled } \\
\text { articles }\end{array}$ & $\begin{array}{l}\geq 1 \\
\text { Scopus } \\
\text { citation }\end{array}$ & $\begin{array}{l}\geq 1 \\
\text { Patent } \\
\text { citation }\end{array}$ & $\begin{array}{l}\geq 1 \mathrm{PPT} \\
\text { mention }\end{array}$ & $\begin{array}{l}\geq 1 \\
\text { Syllabus } \\
\text { mention }\end{array}$ & $\begin{array}{l}\geq 1 \\
\text { Wikipedia } \\
\text { mention }\end{array}$ & $\begin{array}{l}\geq 1 \\
\text { Mendeley } \\
\text { reader }\end{array}$ & $\begin{array}{l}\geq 1 \\
\text { Twitter } \\
\text { mention }\end{array}$ \\
\hline
\end{tabular}




\begin{tabular}{|c|c|c|c|c|c|c|c|c|}
\hline $\begin{array}{l}\text { Language and } \\
\text { Linguistics }\end{array}$ & 312 & $\begin{array}{l}173, \\
(55.4 \%)\end{array}$ & $\begin{array}{l}1, \\
(0.3 \%)\end{array}$ & $\begin{array}{l}0, \\
(0 \%)\end{array}$ & $\begin{array}{l}6, \\
(1.9 \%)\end{array}$ & $\begin{array}{l}2, \\
(0.6 \%)\end{array}$ & $\begin{array}{l}140, \\
(44.9 \%)\end{array}$ & $\begin{array}{l}40, \\
(12.8 \%)\end{array}$ \\
\hline $\begin{array}{l}\text { Developmental } \\
\text { and Educational } \\
\text { Psychology }\end{array}$ & 225 & $\begin{array}{l}196, \\
(87.1 \%)\end{array}$ & $\begin{array}{l}0, \\
(0 \%)\end{array}$ & $\begin{array}{l}3, \\
(1.3 \%)\end{array}$ & $\begin{array}{l}3, \\
(1.3 \%)\end{array}$ & $\begin{array}{l}8, \\
(3.5 \%)\end{array}$ & $\begin{array}{l}172, \\
(76.4 \%)\end{array}$ & $\begin{array}{l}53, \\
(23.5 \%)\end{array}$ \\
\hline $\begin{array}{l}\text { Nutrition and } \\
\text { Dietetics }\end{array}$ & 400 & $\begin{array}{l}376, \\
(94 \%) \\
\end{array}$ & $\begin{array}{l}0, \\
(0 \%)\end{array}$ & $\begin{array}{l}4, \\
(1 \%) \\
\end{array}$ & $\begin{array}{l}1, \\
(0.3 \%) \\
\end{array}$ & $\begin{array}{l}15, \\
(3.7 \%) \\
\end{array}$ & $\begin{array}{l}302, \\
(75.5 \%)\end{array}$ & $\begin{array}{l}193, \\
(48.2 \%)\end{array}$ \\
\hline Veterinary & 141 & $\begin{array}{l}128, \\
(90.8 \%)\end{array}$ & $\begin{array}{l}0, \\
(0 \%)\end{array}$ & $\begin{array}{l}0, \\
(0 \%)\end{array}$ & $\begin{array}{l}0, \\
(0 \%)\end{array}$ & $\begin{array}{l}2 \\
1,4 \%) \\
\end{array}$ & $\begin{array}{l}120, \\
(85.1 \%)\end{array}$ & $\begin{array}{l}30, \\
(21.3 \%)\end{array}$ \\
\hline Biotechnology & 286 & $\begin{array}{l}270, \\
(94.4 \%) \\
\end{array}$ & $\begin{array}{l}2, \\
(0.7 \%)\end{array}$ & $\begin{array}{l}2, \\
(0.7 \%)\end{array}$ & $\begin{array}{l}1, \\
(0.3 \%)\end{array}$ & $\begin{array}{l}3, \\
(1 \%) \\
\end{array}$ & $\begin{array}{l}227, \\
(79.4 \%)\end{array}$ & $\begin{array}{l}49, \\
(17.1 \%)\end{array}$ \\
\hline Neurology & 303 & $\begin{array}{l}296, \\
(97.7 \%)\end{array}$ & $\begin{array}{l}0, \\
(0 \%) \\
\end{array}$ & $\begin{array}{l}4, \\
(1.3 \%) \\
\end{array}$ & $\begin{array}{l}2, \\
(0.7 \%) \\
\end{array}$ & $\begin{array}{l}9, \\
(3 \%) \\
\end{array}$ & $\begin{array}{l}267, \\
(88.1 \%) \\
\end{array}$ & $\begin{array}{l}122, \\
(40.3 \%) \\
\end{array}$ \\
\hline $\begin{array}{l}\text { Organic } \\
\text { chemistry } \\
\end{array}$ & 354 & $\begin{array}{l}339, \\
(95.7 \%) \\
\end{array}$ & $\begin{array}{l}1, \\
(0.3 \%) \\
\end{array}$ & $\begin{array}{l}0, \\
(0 \%) \\
\end{array}$ & $\begin{array}{l}0, \\
(0 \%) \\
\end{array}$ & $\begin{array}{l}3, \\
(0.8 \%) \\
\end{array}$ & $\begin{array}{l}258, \\
(72.9 \%) \\
\end{array}$ & $\begin{array}{l}70, \\
(19.8 \%) \\
\end{array}$ \\
\hline $\begin{array}{l}\text { Computational } \\
\text { Mathematics }\end{array}$ & 334 & $\begin{array}{l}281, \\
(84.1 \%)\end{array}$ & $\begin{array}{l}0, \\
(0 \%)\end{array}$ & $\begin{array}{l}0, \\
(0 \%)\end{array}$ & $\begin{array}{l}0, \\
(0 \%)\end{array}$ & $\begin{array}{l}3, \\
(0.9 \%)\end{array}$ & $\begin{array}{l}191, \\
(57.2 \%)\end{array}$ & $\begin{array}{l}42, \\
(12.6 \%)\end{array}$ \\
\hline Total & 2,355 & $\begin{array}{l}2,059, \\
(87.4 \%)\end{array}$ & $\begin{array}{l}4, \\
(0.2 \%)\end{array}$ & $\begin{array}{l}13, \\
(0.6 \%)\end{array}$ & $\begin{array}{l}13, \\
(0.6 \%)\end{array}$ & $\begin{array}{l}45, \\
(1.9 \%)\end{array}$ & $\begin{array}{l}1677, \\
(71.2 \%)\end{array}$ & $\begin{array}{l}599, \\
(25.4 \%)\end{array}$ \\
\hline
\end{tabular}

Table 3. Bibliometric and altmetric information for the UK articles published in 2012 indexed by Scopus.

\begin{tabular}{|c|c|c|c|c|c|c|c|c|}
\hline Field name & $\begin{array}{l}\text { Sampled } \\
\text { articles }\end{array}$ & $\begin{array}{l}\geq 1 \\
\text { Scopus } \\
\text { citation }\end{array}$ & $\begin{array}{l}\geq 1 \\
\text { Patent } \\
\text { citation }\end{array}$ & $\begin{array}{l}\geq 1 \mathrm{PPT} \\
\text { mention }\end{array}$ & $\begin{array}{l}\geq 1 \\
\text { Syllabus } \\
\text { mention }\end{array}$ & $\begin{array}{l}\geq 1 \\
\text { Wikipedia } \\
\text { mention }\end{array}$ & $\begin{array}{l}\geq 1 \\
\text { Mendeley } \\
\text { reader }\end{array}$ & $\begin{array}{l}\geq 1 \\
\text { Twitter } \\
\text { mention }\end{array}$ \\
\hline $\begin{array}{l}\text { Language and } \\
\text { Linguistics }\end{array}$ & 780 & $\begin{array}{l}\text { 619, } \\
(79.3 \%)\end{array}$ & $\begin{array}{l}0, \\
(0 \%)\end{array}$ & $\begin{array}{l}14, \\
(1.8 \%) \\
\end{array}$ & $\begin{array}{l}27, \\
(3.5 \%) \\
\end{array}$ & $\begin{array}{l}29, \\
(3.7 \%) \\
\end{array}$ & $\begin{array}{l}546, \\
(70 \%)\end{array}$ & $\begin{array}{l}227, \\
(29.1 \%)\end{array}$ \\
\hline $\begin{array}{l}\text { Developmental } \\
\text { and Educational } \\
\text { Psychology }\end{array}$ & 977 & $\begin{array}{l}889 \\
(91 \%)\end{array}$ & $\begin{array}{l}0, \\
(0 \%)\end{array}$ & $\begin{array}{l}22 \\
(2.3 \%)\end{array}$ & $\begin{array}{l}34 \\
(3.5 \%)\end{array}$ & $\begin{array}{l}38, \\
(3.9 \%)\end{array}$ & $\begin{array}{l}890, \\
(91.1 \%)\end{array}$ & $\begin{array}{l}427 \\
(43.7 \%)\end{array}$ \\
\hline $\begin{array}{l}\text { Nutrition and } \\
\text { Dietetics }\end{array}$ & 518 & $\begin{array}{l}491, \\
(94.8 \%)\end{array}$ & $\begin{array}{l}2, \\
(0.4 \%) \\
\end{array}$ & $\begin{array}{l}11 \\
(2.1 \%) \\
\end{array}$ & $\begin{array}{l}1, \\
(0.2 \%) \\
\end{array}$ & $\begin{array}{l}12, \\
(2.3 \%)\end{array}$ & $\begin{array}{l}480, \\
(92.7 \%)\end{array}$ & $\begin{array}{l}318, \\
(61.4 \%)\end{array}$ \\
\hline Veterinary & 276 & $\begin{array}{l}254, \\
(92 \%) \\
\end{array}$ & $\begin{array}{l}0, \\
(0 \%) \\
\end{array}$ & $\begin{array}{l}0, \\
(0 \%) \\
\end{array}$ & $\begin{array}{l}1, \\
(0.4 \%) \\
\end{array}$ & $\begin{array}{l}7, \\
(2.5 \%)\end{array}$ & $\begin{array}{l}253, \\
(91.7 \%)\end{array}$ & $\begin{array}{l}108, \\
(39.1 \%)\end{array}$ \\
\hline Biotechnology & 401 & $\begin{array}{l}383, \\
(95,5 \%)\end{array}$ & $\begin{array}{l}7, \\
(1.7 \%) \\
\end{array}$ & $\begin{array}{l}0, \\
(0 \%)\end{array}$ & $\begin{array}{l}1, \\
(0.2 \%) \\
\end{array}$ & $\begin{array}{l}12, \\
(3 \%)\end{array}$ & $\begin{array}{l}354, \\
(88.3 \%)\end{array}$ & $\begin{array}{l}130, \\
(32.4 \%)\end{array}$ \\
\hline Neurology & 812 & $\begin{array}{l}781, \\
(96.2 \%)\end{array}$ & $\begin{array}{l}1, \\
(0.1 \%)\end{array}$ & $\begin{array}{l}12, \\
(1.5 \%)\end{array}$ & $\begin{array}{l}7, \\
(0.9 \%)\end{array}$ & $\begin{array}{l}21, \\
(2.6 \%)\end{array}$ & $\begin{array}{l}752, \\
(92.6 \%)\end{array}$ & $\begin{array}{l}340, \\
(41.9 \%)\end{array}$ \\
\hline $\begin{array}{l}\text { Organic } \\
\text { chemistry }\end{array}$ & 376 & $\begin{array}{l}363, \\
(96.5 \%)\end{array}$ & $\begin{array}{l}6, \\
(1.6 \%)\end{array}$ & $\begin{array}{l}0, \\
(0 \%)\end{array}$ & $\begin{array}{l}0, \\
(0 \%)\end{array}$ & $\begin{array}{l}2, \\
(0.5 \%)\end{array}$ & $\begin{array}{l}309, \\
(82.2 \%)\end{array}$ & $\begin{array}{l}89, \\
(23.74 \%)\end{array}$ \\
\hline \multirow[t]{2}{*}{$\begin{array}{l}\text { Computational } \\
\text { Mathematics }\end{array}$} & 408 & $\begin{array}{l}376, \\
(92.2 \%)\end{array}$ & $\begin{array}{l}0, \\
(0 \%)\end{array}$ & $\begin{array}{l}3, \\
(0.7 \%)\end{array}$ & $\begin{array}{l}2, \\
(0.5 \%)\end{array}$ & $\begin{array}{l}15, \\
(3.7 \%)\end{array}$ & $\begin{array}{l}284, \\
(69.6 \%)\end{array}$ & $\begin{array}{l}104, \\
(25.5 \%)\end{array}$ \\
\hline & 4,548 & $\begin{array}{l}4,156, \\
(91.4 \%)\end{array}$ & $\begin{array}{l}16, \\
(0.4 \%)\end{array}$ & $\begin{array}{l}62, \\
(1.4 \%)\end{array}$ & $\begin{array}{l}73, \\
(1.6 \%)\end{array}$ & $\begin{array}{l}136, \\
(3 \%)\end{array}$ & $\begin{array}{l}3,868, \\
(85 \%)\end{array}$ & $\begin{array}{l}1743, \\
(38.3 \%)\end{array}$ \\
\hline
\end{tabular}

The altmetric source with the highest coverage for the sampled articles is Mendeley, with $80 \%$ of articles having at least one Mendeley reader, followed by Twitter (34\%). There were very few mentions in Wikipedia (2.6\%), online course syllabi (1.2\%), online PowerPoint presentations (1.1\%) and patents (0.3\%).

\section{Patent citations}


Only $4(0.2 \%)$ Spanish articles and $16(0.3 \%)$ English articles had at least one patent citation, most within biotechnology and organic chemistry. These two fields have a particularly high input of science into technology (Verbeek et al. 2002). Twice as many English articles in biotechnology and chemistry had at least one patent citation ( $1.7 \%$ and $1.6 \%$ respectively) compared to Spain $(0.8 \%$ and $0.3 \%$ respectively). The low results are at partly due to the relatively recent year because patent citations are typically much less recent (Kousha and Thelwall 2015b).

All articles with at least one patent citation also received Scopus citations, except one Spanish language and linguistics article (Development and validation of a measuring instrument for Burnout Syndrome in teachers). For five (biotechnology and chemistry) citations a patent inventor also authored the cited article. Over a third of the patent citations to articles in these fields are therefore self-citations. Individuals who are both authors and inventors play a key role in the linkage between science research and technology development (Breschi et al. 2006).

\section{Presentation citations}

Only 13 (0.6\%) Spanish articles and 62 (1.4\%) UK articles had one or more presentation citations, mostly from psychology, nutrition and neurology. The 84 online PowerPoint presentations citing the sampled articles included slides generated for research/scholarly communication in conferences, webinars and other scientific meetings and slides explaining research projects where the cited publications influenced the project (Table 4). There were also some teaching-related presentations from academic courses, modules and workshops. Both Spanish and UK articles were mostly cited by research-related presentations ( $69 \%$ and $80 \%$ respectively).

Presentations citing the sampled articles were posted mainly on university websites, non-profit organization websites and governmental sites, but some were also posted on company or business websites, educational resources platforms, conference websites, academic social networks (ResearchGate) or academic blogs and wiki sites. No presentations were found in any popular slide sharing sites (slideshare.net, slideshow.com or slideplayer.com).

Table 4. Type of online PowerPoint presentations citing the sampled articles and websites where slides were posted.

\begin{tabular}{|c|c|c|c|c|c|c|c|}
\hline \multirow{2}{*}{$\begin{array}{l}\text { Articles with } \\
\geq 1 \text { PPT citations }\end{array}$} & \multirow{2}{*}{$\begin{array}{l}\text { Presentation } \\
\text { citations }\end{array}$} & \multicolumn{2}{|c|}{ Content type of slides } & \multicolumn{4}{|c|}{ Type of website where slides were posted } \\
\hline & & $\begin{array}{l}\text { Research- } \\
\text { related slides }\end{array}$ & $\begin{array}{c}\text { Teaching- } \\
\text { related slides }\end{array}$ & University & Governt. & $\begin{array}{c}\text { Non- } \\
\text { profit org. }\end{array}$ & Others \\
\hline Spain articles $(n=13)$ & 13 & $69 \%$ & $31 \%$ & $23 \%$ & $23 \%$ & $15 \%$ & $38 \%$ \\
\hline UK articles $(n=62)$ & 71 & $80 \%$ & $20 \%$ & $37 \%$ & $6 \%$ & $20 \%$ & $38 \%$ \\
\hline Total $(n=75)$ & 84 & $79 \%$ & $21 \%$ & $35 \%$ & $8 \%$ & $19 \%$ & $38 \%$ \\
\hline
\end{tabular}

\section{Syllabus mentions}

Only $13(0.6 \%)$ Spanish articles and 73 (1.6\%) UK articles had one or more syllabus mentions. These were most common in language and linguistics and developmental and educational psychology, suggesting that journal articles in these fields may have educational value. There were 99 online course syllabi recommending the sampled articles (Table 5). Out of the 90 academic syllabus mentions, in only $11(12 \%)$ cases, the instructor authored the recommended article (three Spanish and eight UK) and 12 cases could not be checked.

Spanish articles were recommended in course syllabi posted in 16 university websites from 7 countries, especially from the United States (31\%), but also from the UK (19\%), Slovenia (19\%), Israel $(13 \%)$, Spain (6\%), France (6\%) and Thailand (6\%). UK articles were recommended in course syllabi posted in 74 university websites from 17 countries: primarily the United States (46\%), the UK (16\%) and Canada (12\%). 
Table 5. Type of course syllabus mentions citing the sampled articles.

\begin{tabular}{|c|c|c|c|}
\hline \multirow{2}{*}{$\begin{array}{l}\text { Articles with } \\
\geq 1 \text { syllabus mention }\end{array}$} & \multirow{2}{*}{$\begin{array}{l}\text { Syllabus } \\
\text { mentions }\end{array}$} & \multicolumn{2}{|c|}{ Type of course syllabus mentions } \\
\hline & & $\begin{array}{c}\text { Academic syllabus } \\
\text { mentions }\end{array}$ & $\begin{array}{c}\text { Non-academic } \\
\text { syllabus mentions }\end{array}$ \\
\hline Spanish articles $(n=13)$ & 16 & $100 \%$ & $0 \%$ \\
\hline \multirow[t]{2}{*}{ UK articles $(n=73)$} & 83 & $89 \%$ & $11 \%$ \\
\hline & 99 & $91 \%$ & $9 \%$ \\
\hline
\end{tabular}

\section{Wikipedia mentions}

Only 45 (2\%) Spanish articles and 136 (3\%) UK articles had one or more Wikipedia mentions. Most articles (92\%) were mentioned in Wikipedia to support the contributors' statements by including them in the references, bibliography, notes or footnotes section of Wikipedia articles. However, some sampled articles (8\%) were cited in Wikipedia not as referenced material, but as part of the text such as to mention the key work of an award winner.

There were notable language differences in the proportions of Wikipedia citations to the sampled articles (see Table 6). Over a half of the articles with Spanish authorship were cited in English language Wikipedia articles (en.wikipedia.org/wiki/ or en.m.wikipedia.org/wiki/) and the remainder were mainly in Spanish (es.wikipedia.org/wiki/) and other official languages in Spain, such as Catalan and Galician (ca.wikipedia.org/wiki/ and gl.wikipedia.org/wiki/) or French (fr.wikipedia.org/wiki/). Almost three quarters of the citations to articles with UK authorship were from English language Wikipedia articles and the remainder were mainly in German (de.wikipedia.org/wiki/). One article was cited in Scottish Gaelic (gd.wikipedia.org/wiki/). In some cases, there were citations from Wikipedia articles on the same topic in different languages and some of these may have been translations.

Table 6. Language of Wikipedia articles citing the sampled articles.

\begin{tabular}{lcccccc}
\hline \multirow{2}{*}{$\begin{array}{l}\text { Articles with } \geq 1 \\
\text { Wikipedia citation }\end{array}$} & Wikipedia & \multicolumn{4}{l}{ Wikipedia languages } \\
\cline { 3 - 7 } & citations & English & $\begin{array}{c}\text { Spanish \& other } \\
\text { languages of Spain }\end{array}$ & French & German & Others \\
\hline Spain articles $(n=45)$ & 75 & $53 \%$ & $13 \% \& 3 \%$ & $8 \%$ & $4 \%$ & $19 \%$ \\
\hline UK articles $(n=136)$ & 188 & $71 \%$ & $2 \% \& 2 \%$ & $1 \%$ & $6 \%$ & $16 \%$ \\
\hline
\end{tabular}

\section{Mendeley readers}

Almost three quarters (71\%: ranging from $45 \%$ to $88 \%$ ) of the articles with Spanish authorship and $85 \%$ (ranging from $70 \%$ to $93 \%$ ) with UK authorship were saved by one or more Mendeley users. These results are broadly in line with previous studies (e.g., Thelwall and Sud 2015; Mohammadi and Thelwall 2014; Mohammadi et al. 2015; Thelwall and Wilson 2016; Zahedi et al. 2014). The proportions varied from $91.4 \%$ for neurology to $64 \%$ for computational mathematics and $63 \%$ for language and linguistics. The coverage of Mendeley for Spanish articles (45\%) in language and linguistics is particularly low compared to the UK (70\%) (Tables 2-3). Since linguistics is at least partly culture specific, this may reflect a low uptake of Mendeley in Spain, at least within linguistics. According to Ortega (2015), less than $3 \%$ of staff members belonging to the Spanish National Research Council had a profile in Mendeley, although no information regarding disciplines was provided.

\section{Twitter mentions}

A third (34\%) of the articles were tweeted at least once, with fewer Spanish (25\%) than UK (38\%) articles attracting tweets. Previous studies have found lower Twitter coverage: $21 \%$ of about a million 
WoS journal articles published in 2012 (Haustein et al. 2015), 20\% of PubMed/WoS articles published in 2012 (Haustein et al. 2014) and 13\% of over half a million WoS publications published in 2011-2013 (Costas et al. 2015a) received one or more Twitter mentions. This suggests that more articles are now tweeted or that data collection by Altmetric.com is more comprehensive.

Nutrition and dietetics is the field with the highest proportion $(55.7 \%)$ of tweeted articles and computational mathematics has the lowest proportion (19.7\%). This may reflect greater public interest in the former topic than the latter. As shown in Tables 2-3, 13\% of Spanish articles and $29 \%$ of UK articles in Language and Linguistics field were mentioned in Twitter. This is in line with $21 \%$ for Swedish articles from the same year (Hammarfelt 2014). It is possible that the low results suggest that the public has little interest in academic linguistics.

\section{Comparison between Spain and the UK for average indicator values}

For the patent and PowerPoint indicators there were too few non-zero values to compare Spain with the UK. The effect of using the remaining indicators instead of Scopus citations can be evaluated by comparing Figure 1 to Figures 2 to 5. The UK has more Scopus citations than Spain in all subject areas except veterinary and the difference is large enough for Spain not to be within the UK $95 \%$ confidence interval for six of the eight subjects. This is consistent with the hypotheses that UK research has a higher impact than Spain in most subjects or that Scopus has a substantial bias towards the UK or both.

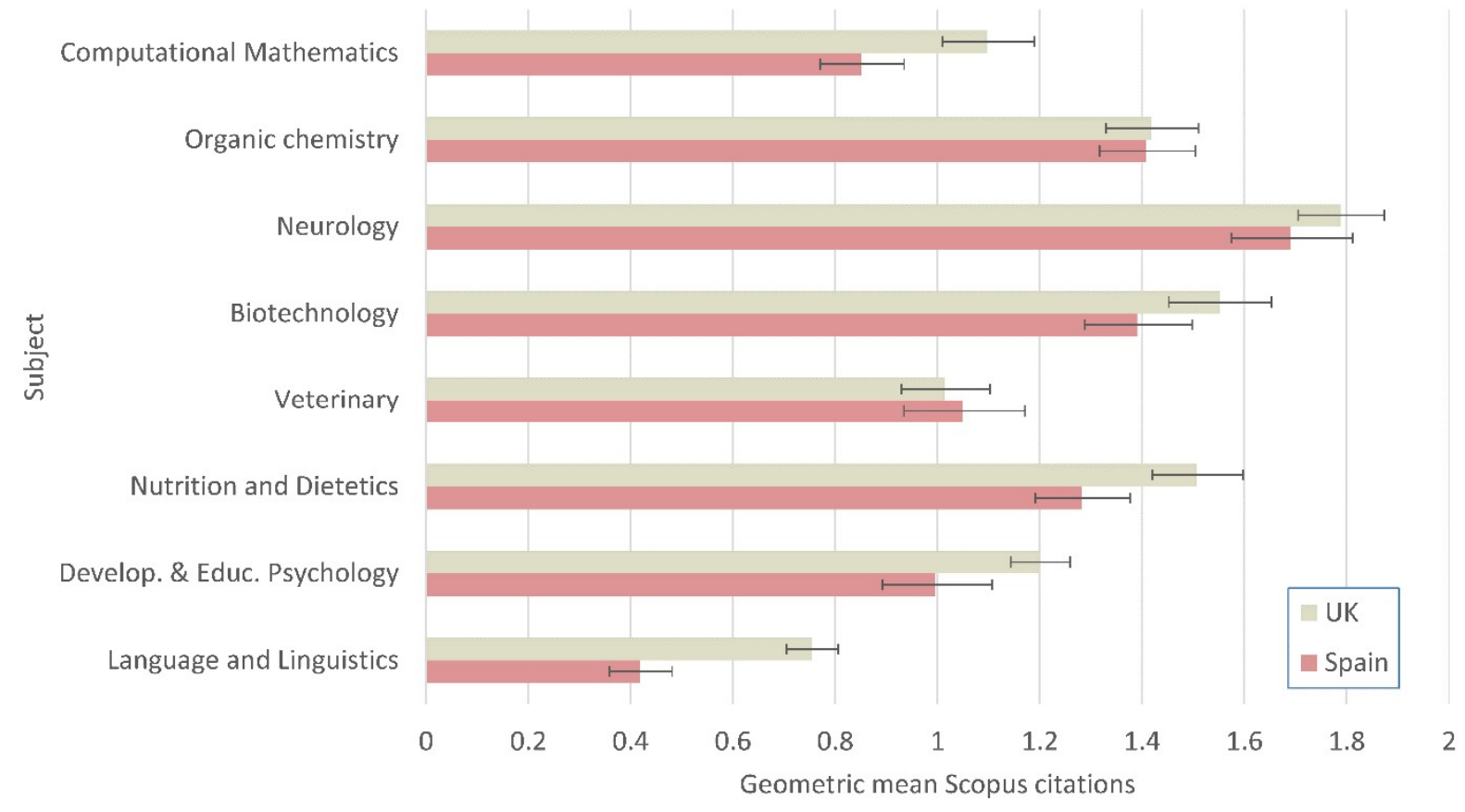

Fig. 1 The geometric mean number of citations per article for Spain and the UK

Switching from Scopus citations to syllabus mentions (Figure 2) would reduce the number of subject areas for which the difference between Spain and the UK is statistically significant from six to two. Whilst this reduces the statistical evidence of a difference between the two countries but the cause is a reduction in the amount of data, leading to wide confidence intervals. The wide conficence intervals for syllabus mentions show that this is not a practical alternative. 


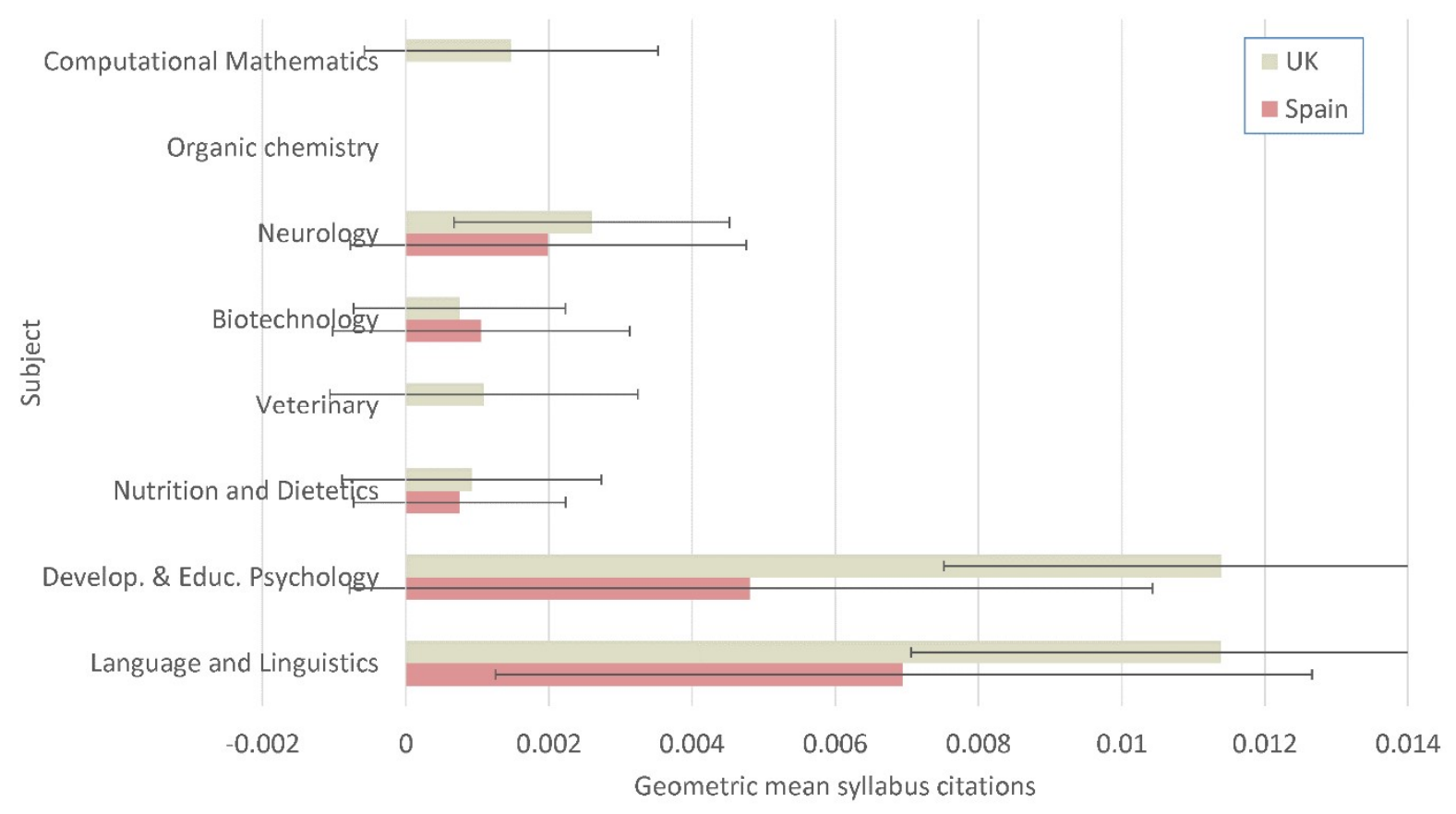

Fig. 2 The geometric mean number of syllabus mentions per article for Spain and the UK. Insufficient data is available for organic chemistry for both countries and for Spain for computational mathematics and veterinary

Switching from Scopus citations to Wikipedia citations (Figure 3) would reduce the number of subject areas for which the difference between Spain and the UK is statistically significant from six to three, with the main cause again being wide confidence intervals due to a reduction in the amount of data. The (not statistically significant) higher values for Spain in half of the categories is promising but Wikipedia citations give too wide confidence intervals for it to be a practical alternative.

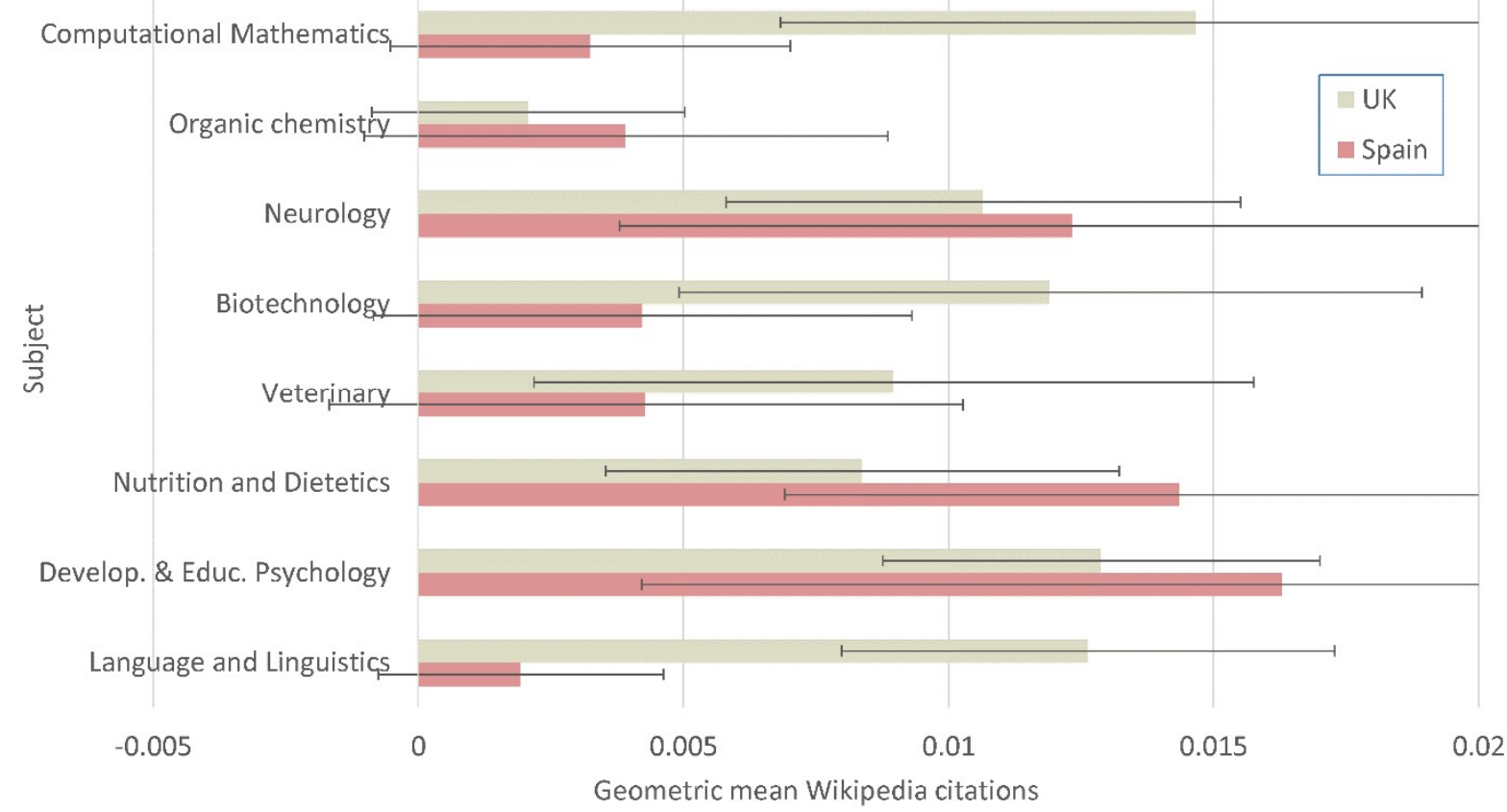

Fig. 3 The geometric mean number of Wikipedia citations per article for Spain and the UK. 
Switching from Scopus citations to Mendeley readers (Figure 4) would increase the number of subject areas for which the difference between Spain and the UK is statistically significant from six to all eight. This is presumably due to much higher uptake of Mendeley in the UK than in Spain. In June 2016, the five countries using Mendeley the most relative to other sites (according to Alexa.com: http://www.alexa.com/siteinfo/mendeley.com) were India, the USA, Malaysia, the UK and Japan. The presence of the UK in this list and the absence of Spain suggest that UK articles will have an advantage relative to Spanish articles in Mendeley because people tend to read articles from their own nation disproportionately often (Thelwall and Maflahi 2015).

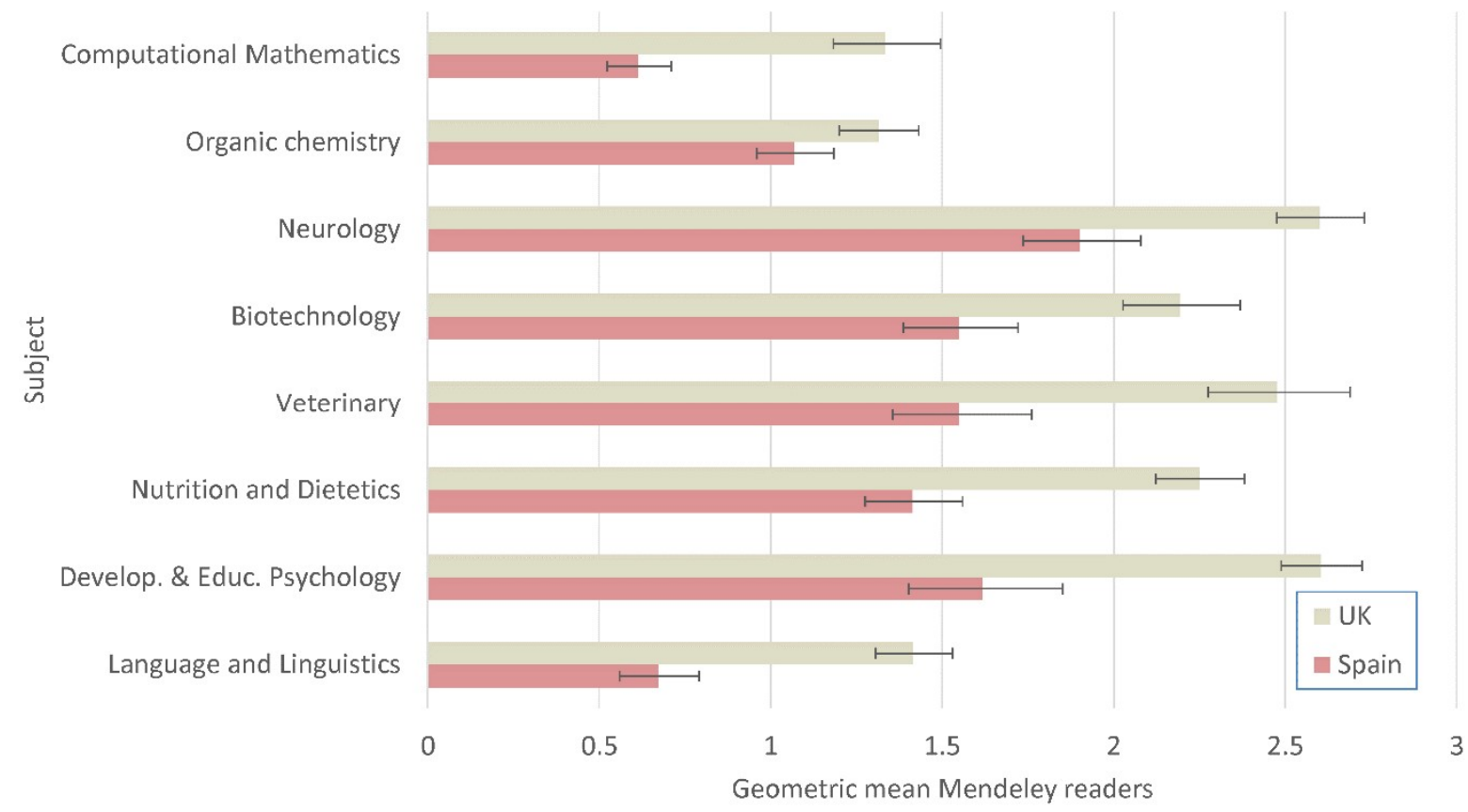

Fig. 4 The geometric mean number of Mendeley readers per article for Spain and the UK

Switching from Scopus citations to tweets (Figure 5) would increase the number of subject areas for which the difference between Spain and the UK is statistically significant from six to all eight. By June 2016 Twitter was more popular in Spain (Alexa rank 8: http://www.alexa.com/topsites/countries/ES) than in the UK (Alexa rank 11: http://www.alexa.com/topsites/countries/GB). Some possible explanations are that UK research in all these areas tends to be better than Spanish reseach, that Spanish researchers don't tend to tweet about academia, or that UK research tends to be more popular in Twitter for other reasons. 


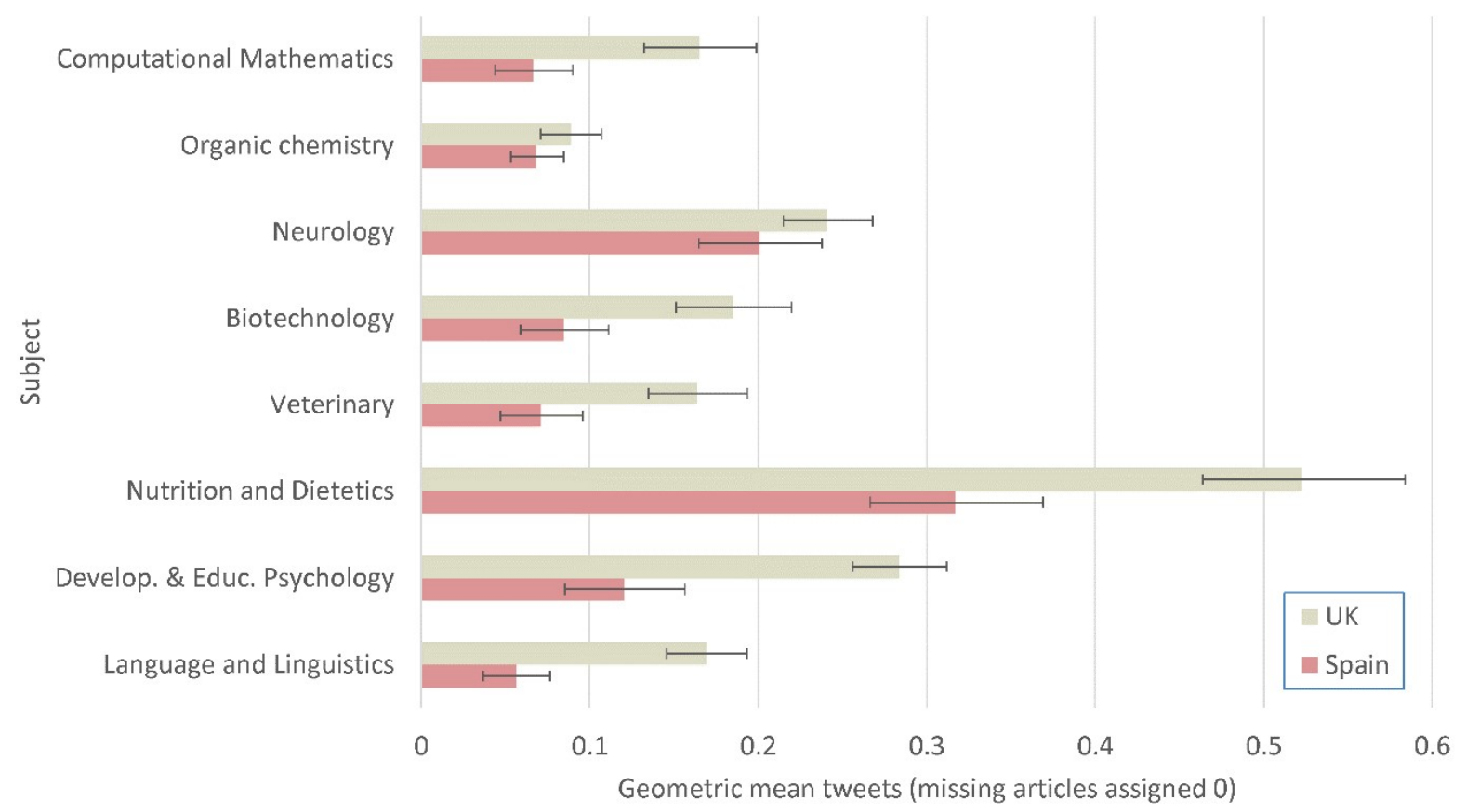

Fig. 5 The geometric mean number of tweets per article for Spain and the UK

\section{Discussion}

This study was restricted to journal articles (excluding other types of publications, such as conferences or review papers) published in a single year (2012) with a DOI available for eight subject fields indexed by Scopus, focused in two countries: Spain and the United Kingdom. The findings should not be generalized to very different fields or to fields in which Spain publishes little.

The selection of Scopus as data source affect the results. In this study Spanish production refers to Scopus journal articles with at least one author affiliated to a Spanish institution and UK production refers to articles with one or more authors affiliated to UK institutions. Scopus has a bias towards English and scholars may choose to publish in their own languages, especially in disciplines with national or regional orientations in the social sciences and humanities (López-Navarro et al. 2015; Nederhof 2006). This at least partly explains the greater UK publishing in the eight selected fields.

In order to extract the social media metrics for the sampled articles, queries were based on the Bing API and Altmetric.com. Results in this study are consequently limited to the results found by them. The API is the only licit source of Bing data for automatic queries (Thelwall and Sud 2012), but it and the main web interface of Bing might give different results (Thelwall and Sud 2012). No search engine covers the whole web and it seems that Bing has a smaller index than Google search engine (Van den Bosch et al. 2016). On the other hand, Twitter mentions were gathered using Altmetric.com and Twitter data does not seem to be persistent across the main altmetric data providers (Chamberlain 2013). Therefore, some relevant online mentions or citations to articles are likely to have been missed.

For practical reasons, we only used two keywords ('syllabus' and 'course description') for the creation of syllabus mentions queries, and this method is likely to miss non-English syllabus mentions. This partly explains the low number of syllabus mentions as well as that most of the academic course syllabi were from the United States and the United Kingdom. More research about reference patterns in academic course syllabi is also needed. For instance, what kind of publications are recommended in course syllabi? Are there discipline and country differences? What proportion of course syllabi are posted online? 
Indicators vary over time. For instance, citations need time to accrue and citation time windows vary across disciplines (Wang 2013) and the longer time periods, the better for assessing the commercial benefit of scientific publications based on patent citations (Kousha and Thelwall 2015b). In contrast, recent publications tend to attract more Twitter mentions than older publications (Haustein et al. 2014). For recent years, older articles tend to attract more Mendeley readers (Thelwall and Sud 2015) but nothing is known about Wikipedia citations over time.

\section{Conclusions}

In response to the first research question, Mendeley is the altmetric source with the highest coverage for the sampled articles, with over three quarters (80\%) of articles having one or more Mendeley readers, followed by Twitter, with a third (34\%) of articles tweeted at least once. The coverage of the remaining sources was very low, with very few mentions in Wikipedia (2.6\%), online course syllabi (1.2\%), online PowerPoint presentations (1.1\%) and online patents $(0.3 \%)$.

In response to the second research question, all of the indicators checked for the subject fields chosen either have too little data (i.e., too many 0 values) or increase the overall difference between Spain and the UK and so none can be suggested as alternatives to reduce the bias against Spain in traditional citation indexes.

As the case of Mendeley illustrates, the outlook for finding web-based indicators that are not internationally biased seems poor. The underlying problem seems to be that the USA and English speaking peoples currently seem to lead most web developments, including most academic web developments, and so web data may be even more biased against non-English nations than are Scopus and the Web of Science. Even if the exceptions, such as Berlin-based ResearchGate.net, could attract disproportionately many non-English researchers then this would create a new type of bias that would be equally unhelpful. Thus, unless in the long term international use of key social websites becomes equalised, it seems unlikely that any web-based indicator would be free of international biases. Thus, if unbiased indicators are to be constructed then bias-correcting methods must be developed and applied to biased data.

\section{References}

ACUMEN Portfolio (2014). Guidelines for Good Evaluation Practice (2014). The ACUMEN Consortium. http://research-acumen.eu/wp-content/uploads/D6.14-Good-Evaluation-Practices.pdf. Accessed 13 December 2015.

Adie, E., \& Roe, W. (2013). Altmetric: enriching scholarly content with article-level discussion and metrics. Learned Publishing, 26 (1), 11-17.

Aibar, E., Lladós-Masllorens, J., Meseguer-Artola, A., Minguillón, J., \& Lerga, M. (2015). Wikipedia at university: what faculty think and do about it. Electronic Library, 33(4), 668-683.

Albarillo, F. (2014). Language in Social Science Databases: English Versus Non-English Articles in JSTOR and Scopus. Behavioral \& Social Sciences Librarian, 33(2), 77-90.

Alonso-Jiménez, E. (2015). Una aproximación a Wikipedia como polisistema cultural. Convergencia: Revista de Ciencias Sociales, 22(68), 125-149.

Archambault, É., Vignola-Gagné, É., Côté, G., Larivière, V., \& Gingrasb, Y. (2006). Benchmarking scientific output in the social sciences and humanities: The limits of existing databases.

Scientometrics, 68(3), 329-342. 
Bollen, J., Van-De-Sompel, H., Smith, J. A., \& Luce, R. (2005). Toward alternative metrics of journal impact: A comparison of download and citation data. Information Processing \& Management, 41(6), 1419-1440.

Bonk, C. J. (2001). Online teaching in an online world. Bloomington, In CourseShare.com. http://www.publicationshare.com/docs/faculty survey report.pdf. Accessed 22 January 2016.

Bornmann, L. (2014). Do altmetrics point to the broader impact of research? An overview of benefits and disadvantages of altmetrics. Journal of Informetrics, 8(4), 895-903.

Breschi, S., Tarasconi, G., Catalini, C., Novella, L., Guatta, P., \& Johnson, H. (2006). Highly Cited Patents, Highly Cited Publications, and Research Networks. European Commission. http://ec.europa.eu/invest-in-research/pdf/download en/final report hcp.pdf Accessed 2 December 2015.

Cabrera Hernández, L. M. (2013). Web 2.0: Wikipedia como fuente de información sobre las ciencias de la alimentación y de la nutrición. Alicante: Universidad de Alicante.

Callaert, J., Van Looy, B, Verbeek, A., Debackere, K., \& Thijs, B. (2006). Traces of Prior Art: An analysis of non-patent references found within patent documents. Scientometrics, 69(1), 3-20.

Chamberlain, S. (2013). Consuming Article-Level Metrics: Observations and Lessons. Information Standards Quarterly, 25(2), 4-13.

Chen, H.-L. (2010). The perspectives of higher education faculty on Wikipedia. Electronic Library, 28(3), 361-373.

Chinchilla-Rodríguez, Z., Corera-Álvarez, E., Moya-Anegón F. de, \& Sanz-Menéndez, L. (2014). La producción científica española en el contexto internacional y la posición de sus instituciones de investigación en el ranking mundial (2009-2013). In M. Parellada (Dir.). Informe CYD 2014 (pp. 220235). Barcelona: Fundación Conocimiento y Desarrollo.

Clauson, K. A., Polen, H. H., Kamel Boulos, M. N., \& Dzenowagis, J. H. (2008). Scope, Completeness, and Accuracy of Drug Information in Wikipedia. The Annals of Pharmacotherapy, 42(12), 1814-1821.

Costas, R., Zahedi, Z., \& Wouters, P. (2015a). Do 'altmetrics' correlate with citations? Extensive comparison of altmetric indicators with citations from a multidisciplinary perspective. Journal of the Association for Information Science and Technology, 66(10), 2003-2019.

Costas, R., Zahedi, Z., \& Wouters, P. (2015b). The thematic orientation of publications mentioned on social media: Large-scale disciplinary comparison of social media metrics with citations. Aslib Journal of Information Management, 67(3), 260-288.

Cronin, B. (2001). Bibliometrics and beyond: Some thoughts on web-based citation analysis. Journal of Information Science, 27(1), 1-7.

Cummings, J. A., Bonk, C. J., \& Jacobs, F. R. (2002). Twenty-first century college syllabi: Options for online communication and interactivity. The Internet and Higher Education, 5(1), 1-19. 
Davis, P. M. (2002). The Effect of the Web on Undergraduate Citation Behavior: A 2000 Update. College \& Research Libraries, 63(1), 53-60.

Doolittle, P. E., \& Siudzinski, R. A. (2010). Recommended Syllabus Components: What Do Higher Education Faculty Include in Their Syllabi? Journal on Excellence in College Teaching, 21(3), 29-61.

Eijkman, H. (2010). Academics and Wikipedia: Reframing Web $2.0+$ as a disruptor of traditional academic power-knowledge arrangements. Campus-Wide Information Systems, 27(3), 173-185.

Engels, T. C. E., Ossenblok, T. L. B., \& Spruyt, E. H. J. (2012). Changing publication patterns in the Social Sciences and Humanities, 2000-2009. Scientometrics, 93(2), 373-390.

Eysenbach, G. (2011). Can Tweets Predict Citations? Metrics of Social Impact Based on Twitter and Correlation with Traditional Metrics of Scientific Impact. Journal of Medical Internet Research, 13(4), e123. doi:10.2196/jmir.2012.

Fairclough, R., \& Thelwall, M. (2015a). More precise methods for national research citation impact comparisons. Journal of Informetrics, 9(4), 895-906.

Fairclough, R., \& Thelwall, M. (2015b). National research impact indicators from Mendeley readers. Journal of Informetrics, 9(4), 845-859.

Fink, S. B. (2012). The Many Purposes of Course Syllabi. Which are Essential and Useful? Syllabus, 1(1). http://www.syllabusjournal.org/syllabus/article/view/161/PDF. Accessed 9 December 2015.

Garavalia, L. S., Hummel, J. H., Wiley, L. P., \& Huitt, W. G. (1999). Constructing the course syllabus: Faculty and student perceptions of important syllabus components. Journal on Excellence in College Teaching, 10(1), 5-21.

García Fernández, E. C., \& Deltell Escolar, L. (2012). La Guía Docente: un reto en el nuevo modelo de educación universitaria. Estudios sobre el mensaje periodístico, 18, 357-364.

García Martín, A. (Coord.) (2012). Manual de elaboración de guías docentes adaptadas al EEES. Cartagena: Universidad Politécnica de Cartagena.

http://www.upct.es/ euitc/documentos/manual guias para web.pdf Accessed 18 December 2015.

Goodrum, A. A., McCain, K. W., Lawrence, S., \& Giles, C. L. (2001). Scholarly publishing in the Internet age: A citation analysis of computer science literature. Information Processing \& Management, 37(5), 661-675.

Graham, M., Hale, S. A., \& Stephens, M. (2011). Geographies of the World's Knowledge. London: Convoco.

Gunn, W. (2013). Social Signals Reflect Academic Impact: What it Means When a Scholar Adds a Paper to Mendeley. Information Standards Quarterly, 25(2), 33-39.

Hammarfelt, B. (2014). Using altmetrics for assessing research impact in the humanities.

Scientometrics, 101(2), 1419-1430.

Haustein, S., Costas, R., \& Larivière, V. (2015). Characterizing Social Media Metrics of Scholarly Papers: The Effect of Document Properties and Collaboration Patterns. PLOS ONE, 10(3), e0127830. doi: 10.1371/journal.pone.0120495. 
Haustein, S., Peters, I., Sugimoto, C. R., Thelwall, M., \& Larivière, V. (2014). Tweeting biomedicine: An analysis of tweets and citations in the biomedical literature. Journal of the American Society for Information Science and Technology, 65(4), 656-669.

Head, A. J., \& Eisenberg, M. B. (2010). How today's college students use Wikipedia for course-related research. First Monday, 15(3). doi: 10.5210/fm.v15i3.2830.

Henning, V., \& Reichelt, J. (2008). Mendeley - A Last.fm For Research? In eScience, 2008: IEEE Fourth International Conference on eScience (pp. 327-328). Indiana, USA. doi:10.1109/eScience.2008.128.

Herbert, V. G., Frings, A., Rehatschek, H., Richard, G., \& Leithner, A. (2015). Wikipedia - challenges and new horizons in enhancing medical education. BMC Medical Education, 15(32), doi: 10.1186/s12909-015-0309-2.

Hertz, B., Van Woerkum, C., \& Kerkhof, P. (2015). Why Do Scholars Use PowerPoint the Way They Do? Business and Professional Communication Quarterly, 2015, 78(3), 273-291.

Holmberg, K. (2015). Altmetrics for Information Professionals - Past, Present and Future. Chandos Publishing.

Holmberg, K., \& Thelwall, M. (2014). Disciplinary differences in Twitter scholarly communication. Scientometrics, 101(2), 1027-1042.

Jamali, H. R., Nicholas, D., \& Herman, E. (2016). Scholarly reputation in the digital age and the role of emerging platforms and mechanisms. Research Evaluation, 25(1), 37-49.

Jaramillo, P., Castañeda, P., \& Pimienta, M. (2009). Qué hacer con la tecnología en el aula: inventario de usos de las TIC para aprender y enseñar. Educación y Educadores, 12(2), 159-179.

Java, A., Song, X., Finin, T., \& Tseng, B. (2007). Why we twitter: understanding microblogging usage and communities. In Proceedings of the 9th WEBKDD and 1st SNA-KDD Workshop 2007 (pp. 56-65). California, USA.

Jeng, W., He, D., \& Jiang, J. (2015). User participation in an academic social networking service: A survey of open group users on Mendeley. Journal of the Association for Information Science and Technology, 66(5), 890-904.

Koppen, L., Phillips, J., \& Papageorgiou, R. (2015). Analysis of reference sources used in drug-related Wikipedia articles. Journal of the Medical Library Association: JMLA, 103(3), 140-144.

Kousha, K., \& Thelwall, M. (2006). Motivations for URL citations to open access library and information science articles. Scientometrics, 68(3), 501-517.

Kousha, K., \& Thelwall, M. (2007). How is science cited on the Web? A classification of google unique Web citations. Journal of the Association for Information Science and Technology, 58(11), 16311644.

Kousha, K., \& Thelwall, M. (2008). Assessing the impact of disciplinary research on teaching: An automatic analysis of online syllabuses. Journal of the American Society for Information Science and Technology, 59(13), 2060-2069. 
Kousha, K., \& Thelwall, M. (2015a). An automatic method for assessing the teaching impact of books from online academic syllabi. Journal of the Association for Information Science and Technology, doi: 10.1002/asi.23542.

Kousha, K., \& Thelwall, M. (2015b). Patent citation analysis with Google. Journal of the Association for Information Science and Technology, doi: 10.1002/asi.23608.

Kousha, K., \& Thelwall, M. (2015c). Web indicators for research evaluation. Part 3: Books and nonstandard outputs. El profesional de la información, 24(6), 724-736.

Kousha, K., \& Thelwall, M. (2016a). Are Wikipedia citations important evidence of the impact of scholarly articles and books? Journal of the Association for Information Science and Technology, doi: 10.1002/asi.23694.

Kubiszewski, I., Noordewier, T., \& Costanza, R. (2011). Perceived credibility of Internet encyclopedias. Computers \& Education, 56(3), 659-667.

Lavsa, S. M., Corman, S. L., Culley, C. M., \& Pummer, T. L. (2011). Reliability of Wikipedia as a medication information source for pharmacy students. Currents in Pharmacy Teaching and Learning, 3(2), 154-158.

Leydesdorff, L., Moya-Anegón, F. de, \& Guerrero-Bote, V. P. (2010). Journal maps on the basis of Scopus data: A comparison with the Journal Citation Reports of the ISI. Journal of the American Society for Information Science and Technology, 61(2), 352-369.

Letierce, J., Passant, A., Breslin, J., \& Decker, S. (2010). Understanding how Twitter is used to spread scientific messages. In Proceedings of the WebSci10: Extending the Frontiers of Society On-Line. Raleigh (NC), 26-27 April. http://journal.webscience.org/314/2/websci10 submission 79.pdf

Leydesdorff, L., Wagner, C. S., Park, H.-W., \& Adams, J. (2013). International collaboration in science: the global map and the network. El profesional de la información, 22(1), 87-94.

Li, X., Thelwall, M., \& Giustini, D. (2012). Validating online reference managers for scholarly impact measurement. Scientometrics, 91(2), 461-471.

Lo, S. S. (2010). Scientific linkage of science research and technology development: a case of genetic engineering research. Scientometrics, 82(1), pp. 109-120.

López-Navarro, I., Moreno, A. I., Quintanilla, M. A., Rey-Rocha, J. (2015). Why do I publish research articles in English instead of my own language? Differences in Spanish researchers' motivations across scientific domain. Scientometrics, 103(3), 939-976.

Luyt, B., \& Tan, D. (2010). Improving Wikipedia's credibility: References and citations in a sample of history articles. Journal of the American Society for Information Science and Technology, 61(4), 715722.

Marta-Lazo, C., Grandío Pérez, M. M., \& Gabelas Barroso, J. A. (2014). La educación mediática en las titulaciones de Educación y Comunicación de las universidades españolas. Análisis de los recursos recomendados en las guías docentes. Vivat Academia, 126, 63-78. 
Mas-Bleda, A., \& Aguillo, I. F. (2015). La web social como nuevo medio de comunicación y evaluación científica. Barcelona: UOC.

Matejka, K., \& Kurke, L. B. (1994). Designing a great syllabus. College Teaching, 42(3), 115-117.

Meyer, M. (2000). What is special about patent citations? Differences between scientific and patent citations. Scientometrics, 49(1), 93-123.

Meyer, M. (2003). Academic patents as an indicator of useful research? A new approach to measure academic inventiveness. Research Evaluation, 12(1), 17-27.

Michel, J., \& Bettels, B. (2001). Patent citation analysis. A closer look at the basic input data from patent search reports. Scientometrics, 51(1), 185-201.

Moed, H. F., \& Halevi, G. (2015). Multidimensional assessment of scholarly research impact. Journal of the Association for Information Science and Technology, 66(10), 1988-2002.

Moed, H. F., \& Visser, M. S. (2007). Bibliometric Indicators of Research Performance in Computer Science: An Exploratory Study'. The Netherlands: Leiden University, Centre for Science and Technology Studies.

Moed H. F., \& Visser, M. S. (2008). Appraisal of citation data sources. A report to HEFCE by the Centre for Science and Technology Studies. Leiden: Leiden University.

http://www.hefce.ac.uk/media/hefce/content/pubs/indirreports/2008/missing/Appraisal\%20of\%20 Citation\%20Data\%20Sources.pdf. Accessed 21 December 2015.

Mohammadi, E., \& Thelwall, M. (2014). Mendeley readership altmetrics for the social sciences and humanities: Research evaluation and knowledge flows. Journal of the American Society for Information Science and Technology, 65(8), 1627-1638.

Mohammadi, E., Thelwall, M., \& Kousha, K. (2016). Can Mendeley bookmarks reflect readership? A survey of user motivations. Journal of the Association for Information Science and Technology, 67(5), 1198-1209.

Mohammadi, E., Thelwall, M., Haustein, S., \& Larivière, V. (2015). Who reads research articles? An altmetrics analysis of Mendeley user categories. Journal of the Association for Information Science and Technology, 66(9), 1832-1846.

Moya-Anegón, F. de, Chinchilla-Rodríguez, Z., Vargas-Quesada, B., Corera-Álvarez, E., MuñozFernández, F. J., González-Molina, A., \& Herrero-Solana, V. (2007). Coverage analysis of Scopus: A journal metric approach. Scientometrics, 73(1), 53-78.

Moya-Anegón, F. de, Chinchilla-Rodríguez, Z., Corera-Álvarez, E., González-Molina, A., López-Illescas, C., \& Vargas-Quesada, B. (2014). Indicadores bibliométricos de la actividad científica española 2011. Informe 2013. Madrid: FECYT.

Narin, F., Hamilton, K. S., \& Olivastro, D. (1997). The increasing linkage between U. S. technology and public science. Research Policy, 26(3), 317-330.

Nederhof, A. J. (2006). Bibliometric monitoring of research performance in the social sciences and the humanities: A review. Scientometrics, 66(1), 81-100. 
Orduña-Malea, E., Ayllón, J. M., Martín-Martín, A., \& Delgado López-Cózar, E. (2014). About the size of Google Scholar: playing the numbers. Granada: EC3 Working Papers, 18: 23.

http://arxiv.org/pdf/1407.6239. Accessed 4 February 2016.

Ortega, J. L. (2015). Relationship between altmetric and bibliometric indicators across academic social sites: The case of CSIC's members. Journal of Informetrics, 9(1), 39-49.

Pfeil, U., Zaphiris, P., \& Ang, C. S. (2006). Cultural Differences in Collaborative Authoring of Wikipedia. Journal of Computer-Mediated Communication, 12(1), 88-113.

Plaza, L. M., \& Bordons, M. (2006). Proyección internacional de la ciencia española. In Enciclopedia del español en el mundo, Anuario del Instituto Cervantes 2006-2007 (pp. 547-567). Madrid: Instituto Cervantes.

Priem, J., \& Costello, K. L. (2010). How and why scholars cite on Twitter. Proceedings of the American Society for Information Science and Technology, 47(1), 1-4.

Priem, J., \& Hemminger, B. M. (2010). Scientometrics 2.0: Toward new metrics of scholarly impact on the social Web. First Monday, 15(7).

Priem, J., Taraborelli, D., Groth, P., \& Neylon, C. (2010). Altmetrics: A manifesto. http://altmetrics.org/manifesto. Accessed 27 November 2015.

Rector, L. H. (2008). Comparison of Wikipedia and other encyclopedias for accuracy, breadth, and depth in historical articles. Reference Services Review, 36(1), 7-22.

Robinson-García, N., Torres-Salinas, D., Zahedi, Z., \& Costas, R. (2014). New data, new possibilities: Exploring the insides of Altmetric.com. El Profesional de la Informacion, 23(4), 359-366.

Rousseau, R., \& Ye, F. Y. (2013). A multi-metric approach for research evaluation. Chinese Science Bulletin, 58(26), 3288-3290.

Schmoch, U. (1993). Tracing the knowledge transfer from science to technology as reflected in patent indicators. Scientometrics, 26(1), 193-211.

Shema, H., Bar-llan, J., \& Thelwall, M. (2012). Research Blogs and the Discussion of Scholarly Information. PLOS ONE, 7(5), e35869.

Shim, J. P., \& Yang, J. (2009). Why is Wikipedia Not More Widely Accepted in Korea and China? Factors Affecting Knowledge-Sharing Adoption. Decision Line, 40(2), 12-15.

Shuai, X., Pepe, A., \& Bollen, J. (2012). How the Scientific Community Reacts to Newly Submitted Preprints: Article Downloads, Twitter Mentions and Citations. PLOS ONE, 7(11), e47523.

Stuart, D. (2009). Social media metrics. Online, 33(6).

http://www.infotoday.com/online/nov09/Stuart.shtml. Accessed 7 February 2016

Thelwall, M. (2009). Introduction to Webometrics: Quantitative Web Research for the Social Sciences. San Rafael, CA: Morgan \& Claypool. 
Thelwall, M., \& Kousha, K. (2008). Online presentations as a source of scientific impact? An analysis of PowerPoint files citing academic journals. Journal of the American Society for Information Science and Technology, 59(5), 805-815.

Thelwall, M., Kousha, K. (2015a). Web indicators for research evaluation. Part 1: Citations and links to academic articles from the Web. El profesional de la información, 24(5), 587-606.

Thelwall, M., \& Kousha, K. (2015b). Web indicators for research evaluation. Part 2: Social media metrics. El profesional de la información, 24(5), 607-620.

Thelwall, M., \& Maflahi, N. (2015). Are scholarly articles disproportionately read in their own country? An analysis of Mendeley readers. Journal of the Association for Information Science and Technology, 66(6), 1124-1135.

Thelwall, M., \& Sud, P. (2012). Webometric research with the Bing Search API 2.0. Journal of Informetrics, 6(1), 44-52.

Thelwall, M., \& Sud, P. (2015). Mendeley readership counts: An investigation of temporal and disciplinary differences. Journal of the Association for Information Science and Technology. doi: 10.1002/asi.23559.

Thelwall, M., Haustein, S., Larivière, V., \& Sugimoto, C. R. (2013). Do Altmetrics Work? Twitter and Ten Other Social Web Services. PLoS ONE, 8(5), e64841.

Thelwall, M., \& Wilson, P. (2016). Mendeley readership altmetrics for medical articles: An analysis of 45 fields. Journal of the Association for Information Science and Technology, 67(8), 1962-1972.

Tijssen, R., Buter, R., \& Van Leeuwen, T. (2000). Technological relevance of science: An assessment of citation linkages between patents and research papers. Scientometrics, 47(2), 389-412

Tsou, A., Bowman, T., Ghazinejad, A., \& Sugimoto, C. (2015). Who Tweets about Science? In Proceedings of the $15^{\text {th }}$ ISSI Conference (pp.95-100). Istanbul, Turkey: Boğaziçi University.

Tung, Y.-T. (2010). A Case Study of Undergraduate Course Syllabi in Taiwan. University of North Texas. http://digital.library.unt.edu/ark:/67531/metadc28487/m2/1/high res d/dissertation.pdf. Accessed 17 December 2015.

Uz, C., Orhan, F., \& Bilgiç, G. (2010). Prospective teachers' opinions on the value of PowerPoint presentations in lecturing. Procedia-Social and Behavioral Sciences, 2(2), 2051-2059.

Van den Bosch, A., Bogers, T., \& Kunder. M. de (2016). Estimating search engine index size variability: a 9-year longitudinal study. Scientometrics, 107(2), 839-856.

Van Leeuwen, T. N., Moed, H. F., Tijssen, R. J. W., Visser, M. S., \& Van Raan, A. F. J. (2001). Language biases in the coverage of the Science Citation Index and its consequences for international comparisons of national research performance. Scientometrics, 51(1), 335-346.

Vaughan, L., \& Shaw, D. (2003). Bibliographic and Web citations: What is the difference? Journal of the American Society for Information Science and Technology, 54(14), 1313-1322. 
Vaughan, L., \& Shaw, D. (2004). Can web citations be a measure of impact? An investigation of journals in the life sciences. Proceedings of the American Society for Information Science and Technology, 41(1), 516-526.

Vaughan, L., \& Shaw, D. (2005). Web citation data for impact assessment: A comparison of four science disciplines. Journal of the American Society for Information Science and Technology, 56(10), 1075-1087.

Vaughan, L., \& Thelwall, M. (2004). Search engine coverage bias: evidence and possible causes. Information Processing \& Management, 40(4), 693-707.

Veletsianos, G. (2012). Higher education scholars' participation and practices on Twitter. Journal of Computer Assisted Learning, 28(4), 336-349.

Verbeek, A., Debackere, K., Luwel, M., Andries, P., Zimmermann, E., \& Deleus, F. (2002). Linking science to technology: Using bibliographic references in patents to build linkage schemes. Scientometrics, 54(3), 399-420.

Wang, J. (2013). Citation time window choice for research impact evaluation. Scientometrics, 94(3), 851-872.

Web-based Education Commission (2000). The Power of the Internet for Learning: Moving from Promise to Practice. Washington: U.S. Department of Education. https://www2.ed.gov/offices/AC/WBEC/FinalReport/WBECReport.pdf. Accessed 28 December 2015.

Weller, K., Dornstädter, R., Freimanis, R., Klein, R. N., \& Perez, M. (2010). Social Software in Academia: Three Studies on Users' Acceptance of Web 2.0 Services. In Proceedings of the 2nd Web Science Conference (WebSci10): Extending the Frontiers of Society On-Line. April 26-27th, Raleigh, North Caroline, United States.

Weller, K., Dröge, E. \& Puschmann, C. (2011). Citation Analysis in Twitter: Approaches for Defining and Measuring Information Flows within Tweets during Scientific Conferences. In Proceedings of the ESWC2011 Workshop on Making Sense of Microposts (pp. 1-12). Heraklion, Greece.

Welsh, T. (2000). An Evaluation of Online Syllabi in The University of Tennessee College of Communications. ALN Magazine, 4(2). Accessed 28 December 2015, https://www.researchgate.net/profile/Teresa Welsh

Wouters, P., Thelwall, M., Kousha, K., Waltman, L., Rijcke de, S., Rushforth, A., \& Franssen, T. (2015). The Metric Tide: Literature Review (Supplementary Report I to the Independent Review of the Role of Metrics in Research Assessment and Management). HEFCE. doi: 10.13140/RG.2.1.5066.3520.

Zahedi, Z., Costas, R., \& Wouters, P. (2014). Assessing the Impact of Publications Saved by Mendeley Users: Is There Any Different Pattern Among Users? In Proceedings of the $35^{\text {th }}$ IATUL Conferences (Paper 4). Espoo, Finland. http://docs.lib.purdue.edu/iatul/2014/altmetrics/4

Zaugg, H., West, R. E., Tateishi, I., \& Randall, D. L. (2011). Mendeley: Creating Communities of Scholarly Inquiry Through Research Collaboration. TechTrends, 55(1), 32-36. 